\title{
1. Measuring finance for the economy and finance for finance
}

\section{Marcello Spanò}

\section{INTRODUCTION}

This work proposes a new approach to measuring the creation of finance in excess of the quantity needed by the real economy, and to assess how finance is distributed across sectors. The methodology is validated by examining yearly changes that occurred in sectorial balance sheets in 14 founder countries of the European Union from 1995 to 2015.

Measuring the superfluous amount of finance in Europe is relevant for at least three reasons. First, a general reason is that finance is crucial in economic analysis. In modern industrialised economies the economic system is a monetary economy of production, where the production of goods and services cannot take place without the opportune creation and circulation of financial capital. Finance is needed in each period to both reactivate existing real activities and provide funds for new activities (Schumpeter, 1912; Keynes, 1937; Graziani, 2003; Godley and Lavoie, 2007; Keen, 2010). ${ }^{1}$ The present study empirically identifies the flows of finance that are inessential to carry out the process of economic production and provides the basis for a discussion on reforms aimed at restoring and safeguarding the crucial role of the financial system.

The second reason is that the role of finance has changed in quality and quantity over the last three decades. This has been investigated by a strand of studies on the financialisation of the economy which has addressed different aspects: single individuals enhancing indebtedness, risk-taking positions and participation in financial markets (Lapavistas, 2011; Martin, 2002); corporate management increasingly targeted at maximising shareholder value (Gallino, 2005; Krippner, 2005); financial assets increasingly used as sources of profitability instead of real production (Epstein, 2005; Erturk et al., 2008; Pollin, 2007; Van Treeck, 2009). The financialisation of the economy has also been associated with income polarisation and inequality (Onaran et al., 2011; Palma, 2009; Stockhammer, 2015), with endogenous financial instability and global imbalances (Crotty, 2008; 
Keen, 2011; Kindleberger, 1986; Minsky, 1986; Nersisyan and Wray, 2010), and with the inadequacy of regulation (Lordon, 2011). This study provides new evidence for the analysis of financialisation by detecting how superfluous financial flows grow and how they are allocated, subject to overarching accounting constraints, between sectors which have different functions (purchasing power creators vs users) and between different economic activities (real production vs. wealth appropriation).

The third reason relates specifically to the debate on the advanced European economies, which are still trapped in a low demand and production equilibrium. Different studies of European economies have already underlined how macroeconomic imbalances can be traced back to institutional flaws within the Eurozone, which is characterised by a common currency (and clearing account system), by the separation of monetary and fiscal authorities, and by bank balance sheets and household debt growing in an uncontrolled way (Wray, 2012; De Grauwe, 2013; Storm, 2016; Lavoie, 2015; Mitchell, 2016). Whatever strategy is suggested to resolve the problem, it is generally agreed that downsizing the financial sector and increasing regulation is an essential step to restore stability and growth (Febrero et al., 2018). The present work provides new empirical tools to examine and reinterpret the imbalances in Europe in terms of the creation of excessive finance. What is more, such a phenomenon is not exclusively associated with the set of rules adopted within the Eurozone, but rather with rising financial integration across all European economies, including those that have kept their national currencies.

The financial flows of the 14 countries of the European Union (EU14) examined in this work are divided into three different components: (i) transactions in financial assets that are associated with the process of real economic decisions on production and spending; (ii) transactions in financial assets that are not clearly related to economic transactions; (iii) changes in the market value of existing and newly created financial assets. As the first two components cannot be distinguished from official accounting, two proxies are here proposed as analytical tools to separate them and to provide measures of deliberately created excessive, unnecessary finance.

Financial flows are analysed by separating and quantifying flows that are channelled into the real sectors of the economy and flows that only circulate within the financial sector at the international level. To this end, the institutional sectors of the economies are grouped into two macro sectors on the basis of their ability to create and/or control the allocation of purchasing power. The foreign sector and domestic financial sector are treated as a single macroeconomic sector responsible for creating, distributing and directing financial flows across sectors and countries. The second macro sector aggregates all the domestic sectors that need financial 
flows to carry out economic production and transactions. It aggregates households, non-financial corporations and the government. The main function of the real domestic sector is to generate most of the value added by using the financial sources available.

The remainder of the chapter is organised as follows: Section 2 describes the accounting framework and defines the proxies and variables used for the empirical analysis; Sections 3 and 4, respectively, report the results of the two proxies, identifying superfluous flows of finance; Section 5 reports the results on volumes of flows generated by transactions (separated into formal and informal assets) in comparison with valuation effects due to market price changes; Section 6 concludes.

\section{ACCOUNTING FRAMEWORK AND METHODOLOGY}

The collected dataset provides information on financial flows within the 14 founder countries of the European Union (EU14), on a sector-by-sector basis, over 21 years (1995-2015). Data have been collected from Eurostat, Annual sector accounts (ESA2010). ${ }^{2}$ In line with the stock-flow accounting tradition (Godley and Lavoie, 2007), this study builds on a fully integrated dataset reporting economic transactions, financial transactions and revaluation of assets. This approach makes it possible to monitor how financial flows are distributed across all sectors of the economy, how this distribution changes over time, how major changes in investment and saving are related to changes in financial transactions, and to changes in the value of net assets.

\section{Definitions and Aggregation}

Table 1.1 reports two examples, referring to the year 2006 for the UK and Spain, of the accounting matrix integrating the transaction flows of sectors and the changes in values of the financial stocks from balance sheets. This includes three sections. The first reports conventional income and expenditure flows, aggregated in the saving and investment. Saving (line a) is what is left from disposable income after taking out consumption and adding net capital transfer. Investment (line b) refers to real capital and excludes financial assets, therefore it aggregates gross fixed capital formation, changes in inventories, acquisitions less disposals of valuables, acquisition less disposals of non-produced non-financial assets. ${ }^{3}$ The balancing item in line A, Net saving, is the difference between saving and investment. 


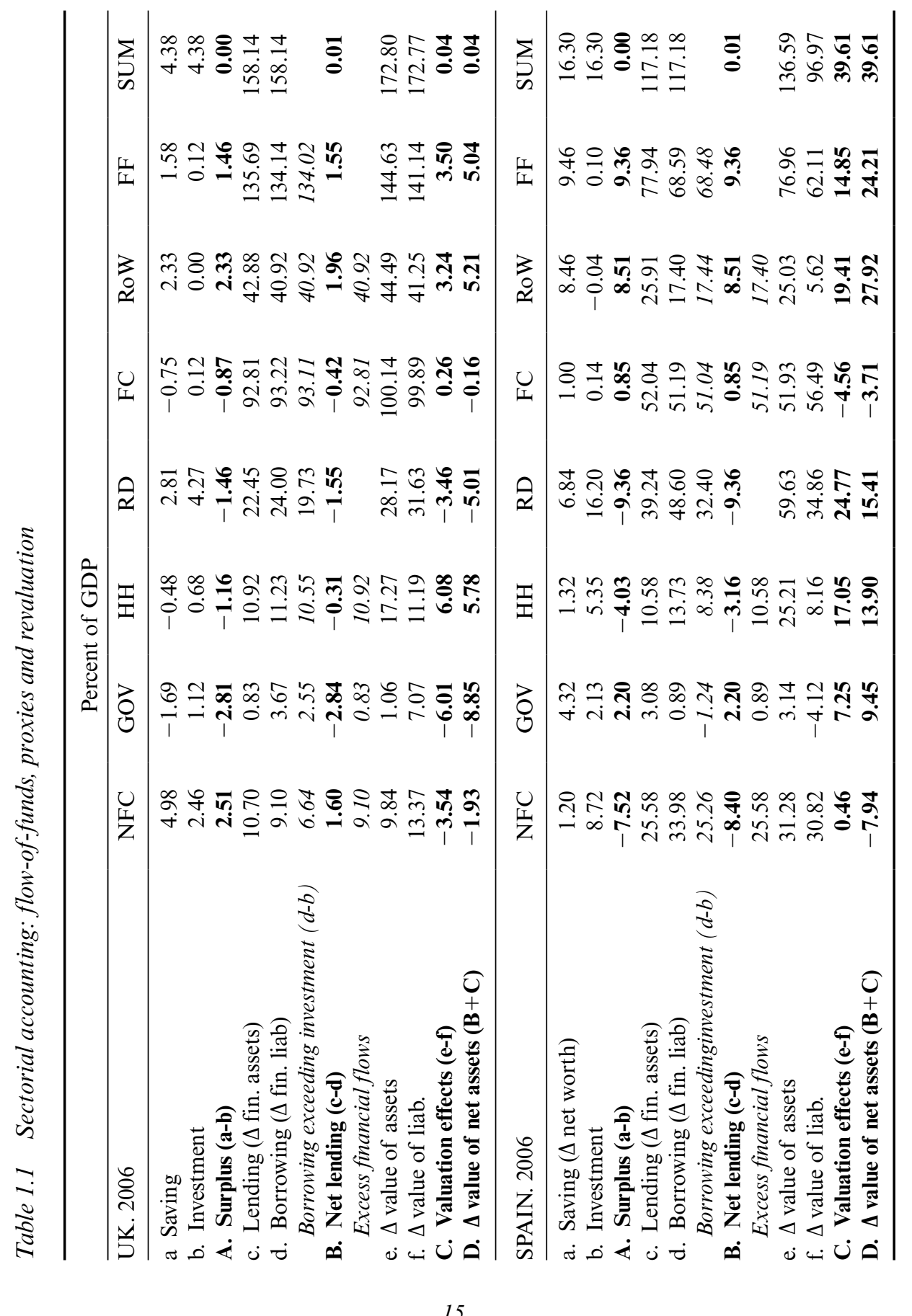


The second section reports flows of assets and liabilities arising from financial transactions. Lending (line c) refers to net acquisition of financial assets, Borrowing (line d) to net incurrence of financial liabilities, both items balancing in line B, Net lending. Consistency across flows is assured by the fact that the sum of sectorial deficits and surpluses of an economy must be equal to zero. This must be verified when the balances of both non-financial (line A) and financial (line B) transactions are considered, the difference being due to statistical discrepancy.

The third section reports changes in the values of assets and liabilities that do not arise from financial transactions. These include the revaluation of assets (nominal holding gains $(+) / \operatorname{losses}(-)$ ) and other changes in volumes. They aggregate the changes in the value of financial stocks (assets in line e, liabilities in line f) that had occurred by the end of the accounting period. Stocks refer to all financial assets (liabilities), whether they are inherited from the previous period or added in the accounting period. Line C, Valuation effects, balances changes in the value of assets and liabilities.

The sectors considered are the 5 institutional sectors defined by the ESA accounting agreement: non-financial corporations (NFC), General government (GOV), Households and Non-profit institutions servicing households (HH), Financial corporations (FC) and Rest of the World (RoW). For the purposes of separating and quantifying flows that are channelled to the real sectors of the economy, and flows that only circulate within the financial sector at the international level, throughout this work these institutional sectors are also grouped into two macro sectors: real domestic sector (RD) aggregating NFC, GOV and $\mathrm{HH}$; and foreign and financial sector (FF) aggregating FC and RoW.

This choice of aggregation is likely to generate perplexity in some readers with a background in post-Keynesian thinking. According to the circuitist viewpoint (Rochon, 1999; Keen, 2015) it is incorrect to consider the whole financial sector as a creator of financial flows, as only the banks play this role by issuing new credit, whereas the non-bank financial institutions deal with the portfolio allocation of pre-existing stocks. This study is well aware of the specific role of the banking system in creating credit ex nihilo. However, its purpose is to measure excess finance in a context where the financialisation of the economy has increased the complexity of financial instruments. The emphasis is on the ability of the whole international financial sector not only to create new credit, but also to control, direct and allocate the quantity and value of the financial wealth (including the existing assets inherited from the past). Moreover, even from a circuitist viewpoint, non-bank institutions can be interpreted as symbiotic to the banking system in creating a liquid short-term store of 
wealth that can be considered as near-monies (Michell, 2017). A second perplexity might arise from readers who adopt the viewpoint of the Modern Money Theory (MMT). In their view, the choice of classifying the government as a sector that does not create money can be criticised as the government is the only possible issuer of the net financial assets held by the non-government sector (Wray, 2012; Mitchell, 2016). The definition of government by the MMT, however, considers the treasury and the central bank as a single consolidated sector. While this perspective can be fully endorsed from a theoretical point of view, there are two reasons why it is not adopted in this work. The first is that the central bank represents a supranational institution in 10 countries of the Eurozone, out of the EU14 group; therefore, it would be a difficult task to consider it as part of a single country's consolidated government sector. The second reason is that the MMT view that government finance is substantially unconstrained is not shared by actual practice in the EU, which is driven by the mainstream theory that government spending needs to be funded by either taxes or private saving. The outcome is that national governments often behave as if they were constrained. Moreover, apart from self-imposed rules, as the authors promoting MMT clearly underline, national governments in the Eurozone are truly money users without being money issuers, and their debt is no longer default-free.

\section{Proxies and Variables Under Observation}

The value of financial assets or liabilities can change as a result of three components: (i) transactions in financial assets that are a direct counterpart of economic transactions; (ii) transactions in financial assets that are not clearly related to economic transactions; (iii) changes in the market value of existing and newly created financial assets.

Accounting rules alone do not allow us to distinguish between the first and the second components. However, it should be clear that, while a sector's net lending is of the same amount as its surplus, gross lending and borrowing items are virtually unlimited. Asset creation and transactions, generally speaking, are not the simple effect of net saving flows adding to existing stocks. Lending does not need prior saving, it needs the availability of means of payments (typically, a line of bank credit). Borrowing might not be channelled to real expenditure in newly produced goods and services, but to purchasing a stock of assets (either real or financial).

To assess how, each year, transactions in financial flows can be delinked from sectorial real transactions in produced goods and services, two proxies are here defined (and reported in Table 1.1). 
The first proxy measures sectorial Borrowing exceeding investment. It takes inspiration from the theory of Schumpeter (1912), according to which the fundamental role of newly issued credit is to finance a change in the productive system. The liabilities of a sector exceeding its investment are interpreted as a signal that this sector has increased borrowing to undertake transactions that are not related to new productive capacity. The mirror image of this process is lending exceeding saving, which is identically equal to the exceeding incurrence of liabilities, given the accounting rule that the net lending of a sector is equal to its surplus.

The second proxy defines Excess financial flows (EFF) with respect to the sectorial net lending position (line B). This takes inspiration from the idea that the financial sector makes sure that sectors in surplus are final holders of the financial liabilities of sectors in deficit. As sectors in deficit are net borrowers by definition, financial flows in excess arise from the amount of borrowing exceeding their deficit. Given that:

\section{Borrowing $(d)-$ Net borrowing $(d-c)=$ Lending $(c)$,}

the proxy EFF of a sector in deficit is equal to its (gross) lending. Similarly, as sectors in surplus are net lenders, EFF takes the value from the amount of the sector's (gross) borrowing. To focus on the creation and allocation of additional flows of superflous finance, negative values of EFF are set equal to zero.

Valuation effects are the last element of the chain going from economic transactions to changes in gross and net financial assets, the latter being accounted in the sectorial balance sheets. They will be examined separately from the flows of financial assets arising from transactions. As value changes, roughly speaking, are determined by price movements in financial markets, they are not intrinsically connected with sectorial surplus and deficit positions. It may thus happen that a sector registers a negative change in the overall value of its net financial assets even though it realises a surplus from economic transactions (see NFC in UK in 2006, Table 1.1). Moreover, the sum of the valuation effect of all sectors is not bound to be zero, as it depends on the composition of the asset portfolios.

Throughout the analysis (see below), financial assets are broken down into two quantities, here labelled formal and informal claims. Formal claims are fixed income commitments to other sectors, that is, all claims legally binding on a nominal value determined at the date they are issued: failure to pay the holder implies bankruptcy of the issuer disciplined by law; they include money items, debt securities and loans. Informal claims are the residual, non-fixed income categories (equities, insurance, pensions, 
financial derivatives and other accounts), plus fixed income claims whose counterpart is from the same sector. By separating formal and informal claims, it is possible to observe items and commitments of different characteristics, in terms of market value exposure.

\section{BORROWING EXCEEDING INVESTMENT}

In the examination of the first proxy, borrowing exceeding investment, we focus on aggregate sectors to underline the connection between sectors that collect and create purchasing power (FF) and sectors that use it (RD), as illustrated in Figure 1.1 for some selected countries (the UK, France, Spain, Germany). The figure decomposes total borrowing into investment plus borrowing exceeding investment and (mirror side) total lending into saving plus lending exceeding saving. The continuous line reports the balance of the RD sectors, which is approximately equal to the country's current account (as the FC balance is nearly zero).

We first analyse borrowing exceeding investment for RD sectors in isolation, to quantify the size of financial flows available to the real economy which exceed its investment in productive capacity. Subsequently, we compare the same proxy with that of the FF sectors, to quantify the financial flows that do not even seem to be channelled to the RD sector.

The RD sectors of the economy appear to have increased their borrowing in excess of their investment over the two decades considered, and they did so at a higher intensity in the period 1999-2007, with a median value of around $12 \%$ of GDP per year. The trend towards increasing borrowing beyond investment continued even during and after the credit crunch crisis (Spain is the only country where the RD sector deleveraged during the credit crunch period). The distribution of flows within the RD sectors has changed over time: from 1999 to 2002, the years of the bubble in the stock market brought about by the dotcom companies, the rise in assets from transactions was led by non-financial corporations (NFC), which increased excess liabilities by $38.7 \%$ (median level) over 4 years. In the following period, culminating in the credit crunch crisis (2003-2007), characterised by credit financing (mainly) housing and consumption levels, the Households sector $(\mathrm{HH})$ also remarkably increased its excess financial positions: excess borrowing increased by $15.2 \%$ over 5 years. During the years of the great recession, the rise in excess liabilities of the RD sector as a whole can be mainly attributed to GOV, to facilitate the restoration of the private sector's balance sheets to more sustainable positions in terms of both risk exposure and net worth, whereas NFC remained nearly unchanged and HH slightly decreased. 

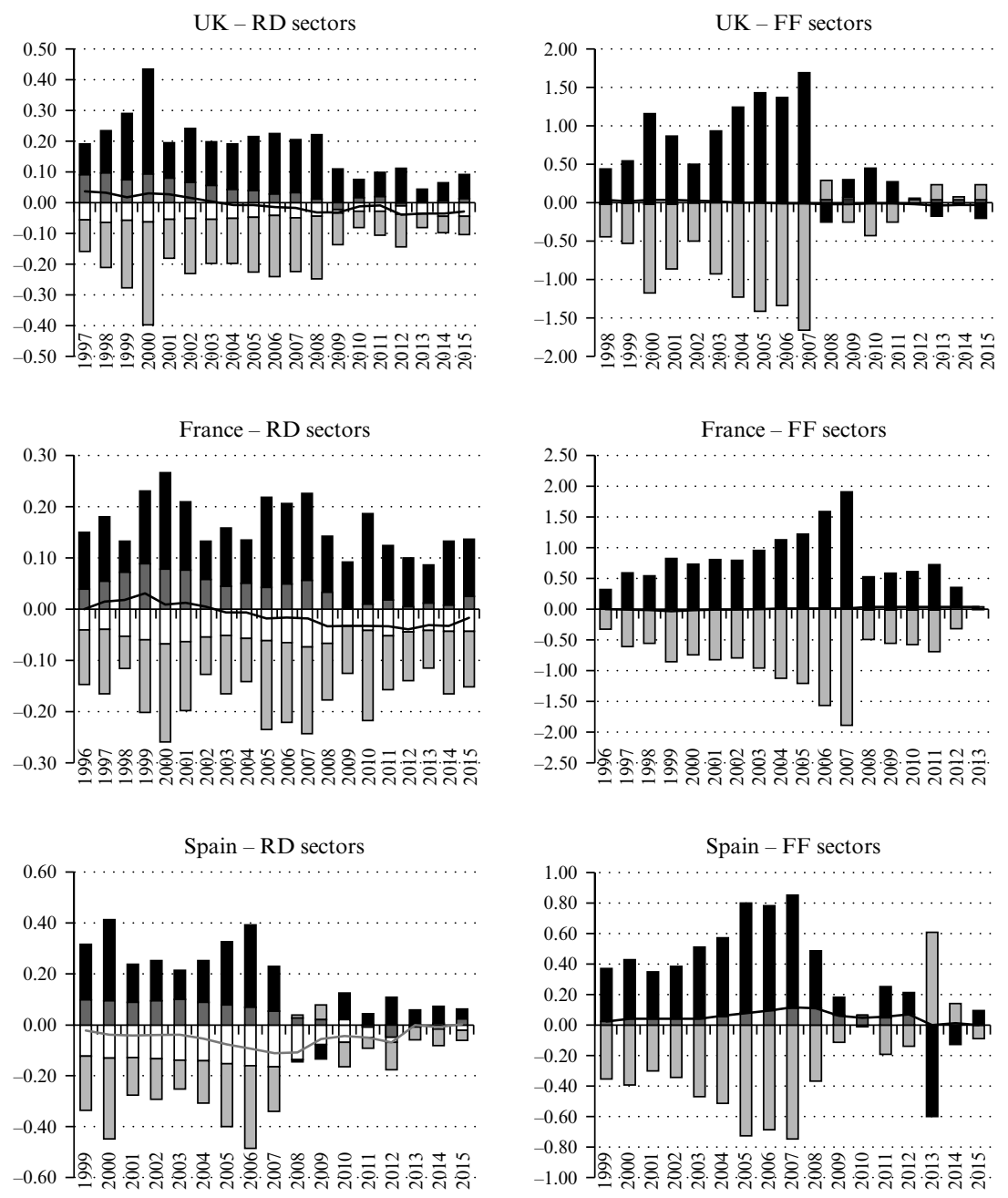

$\square$ Saving $\square$ Investment $\square$ Over_lending $\square$ Over_borrowing - Surplus

Figure 1.1 Saving and investment vs. lending and borrowing

Comparing the FF and RD sectors, the difference in the size of lending and borrowing is striking. As accounting rules imply that the net lending of RD and FF are perfectly balanced, the systematically higher gross financial flows in the FF sector should be interpreted as flows of funds that are likely to be generated and transacted within the FF sector, thus across domestic and foreign financial organisations, without flowing through the 

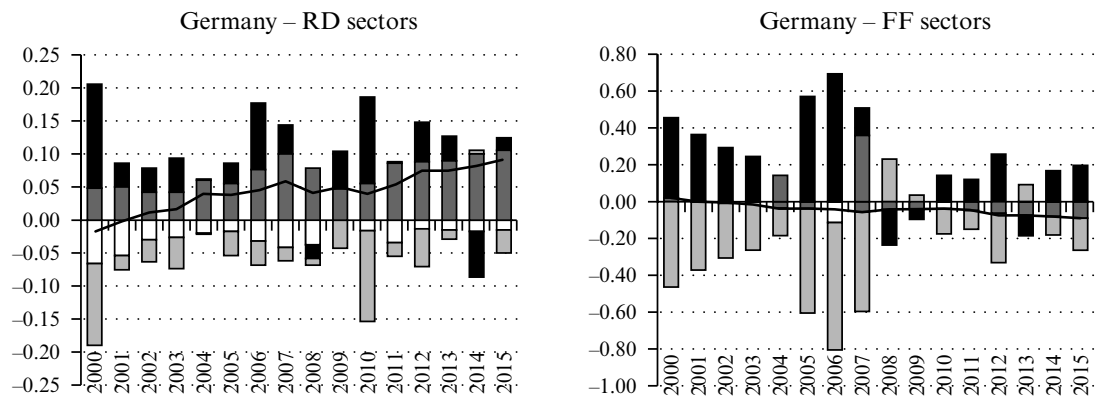

$\square$ Saving $\square$ Investment $\square$ Over_lending $\square$ Over_borrowing $\longrightarrow$ Surplus

\section{Figure 1.1 (continued)}

RD sector. The yearly median value of borrowing exceeding investment was $43 \%$ of GDP from 1999 to 2002 (30\% higher than RD) and 67\% (55\% higher than RD) from 2003 to 2007 . The crisis and the following years of great recession have hit gross financial flows more dramatically in the FF sectors, where they were disproportionate compared to RD; however, they have not clearly inverted (only restrained) the process of enhancing financial balance sheet items from transactions.

Borrowing exceeding investment can be interpreted, in the light of Schumpeter's analysis, as a measure of the new credit that is not used for its essential purpose, which is, precisely, to finance the new investment (Schumpeter, 1912). ${ }^{4}$ The proxy reveals that a large share of the new borrowing is used to purchase existing financial assets, thereby adding 'to society's debt level without increasing its productive capacity' (Keen, 2011, p.339). Borrowing in excess of the productive needs does not enhance the prosperity of the society as a whole, although it can be profitable. Especially in a context of rising stock prices (in both the stock market and housing market), banks may consider a customer wishing to purchase existing wealth as safer and more creditworthy than one planning to transform the productive structure of the economy. Back in 1936 Keynes had already underlined, in his Chapter XII of the General Theory, that the development of the 'organised investment markets' changed the nature of the investment, from the entrepreneurial one - irrevocable and based on genuine knowledge and non-measurable returns - to a portfolio one - revisable and based on conventional knowledge and tentative measurements of risky outcomes (Keynes, 1936, pp.152-3). The observed excess lending (and borrowing) is consistent with this change in perspective and suggests that banks have adapted their conventional assessment of customer creditworthiness to suit a widespread, long term wave of rent-seeking practices (Palma, 2009). 


\section{EXCESS FINANCIAL FLOWS}

The second proxy isolating the flows of financial transactions that are not clearly related to real economic activities, EFF, is equal to gross lending for a net borrower sector and to gross borrowing for a net lender sector (see Table 1.1). Two observations will be raised in relation to this second proxy: one is theoretical, the other is technical.

The first observation is that EFF is more flexible, in theoretical terms, than the proxy in the previous section, as it is not limited to the view that 'normal' or 'essential' borrowing should be equal to the investment. The idea behind the EFF proxy is that essential financial flows are needed to assist the real economic process by guaranteeing the connection between surpluses and deficits at any stage of the circuit. In a simple scheme of a pure credit economy, initial finance corresponds to a creation of financial funds (deposits) available to the producer. These are immediately transferred to pay wages and constitute households' income (surplus), which is equal to firms' investment (deficit). In the final stage of the circuit, firms collect back (part of) the cash balances from households by either selling goods (for consumption) or by issuing equities (Godley and Lavoie, 2007). This, in principle, should allow the firms to reduce their outstanding loans, even though, in practice, finance is rolled over to restart the circuit (Keynes, 1937; Keen, 2010, 2011). EFF captures the financial flows that are generated in addition to this needed finance, since, at the date of accounting, it measures the amount of borrowing exceeding a sector's deficit or the amount of lending exceeding a sector's surplus.

The second observation is a warning about the way numbers will be interpreted. As the data are non-consolidated, sectorial measures of EFF, by definition, include lending (and borrowing) between subjects aggregated in the same sector (for instance, a non-financial firm holding obligations of another non-financial firm). As intra-sector lending is not automatically interpretable as non-essential, EFF levels might overestimate excess finance. To minimise the intra-sectorial component, the proxy is applied to the five institutional sectors, and not to the RD and FF macro sectors. Given this caveat, we shall consider the proxy as more effective at interpreting excess finance if we focus on dynamics over time and on relative levels rather than on absolute levels.

To provide a different perspective from the last section, the size of a sector's EFF is divided by the GDP of all EU14 countries (not by a single country's GDP). The sum of all countries' sectorial EFF is economically meaningful: it is a proxy for non-essential financial transactions globally associated with the same sector in the whole EU14 economy. Figure 1.2 illustrates the results. 
The overall picture emerging with the EFF proxy for financial transactions unrelated to the real economy is similar to and consistent with that described in the last section referring to borrowing exceeding investment. All RD sectors increase the excess financial flows over the period considered: $\mathrm{NFC}$ and the $\mathrm{HH}$ sectors before and GOV after the crisis. The peak of EFF for the NFC sector is in 2000 (nearly $18 \%$ of EU14 GDP) and not in 2006 (nearly 11\%) as for the other private sectors (HH, FC, RoW). The EFF of the $\mathrm{HH}$ sector fluctuates between $4 \%$ and $6 \%$ of EU14 GDP before 2008 and then drastically decreases below 2\%. The high EFF from 1999 to 2007 can be associated to the massive amount of credit flowing to households to finance housing, consumption and acquisitions of financial assets out of their disposable income allowance. After 2008, credit to households has dropped, as has the EFF. National governments try to cushion the consequence of the crisis by increasing excess borrowing, and thereby EFF, to help other sectors to reduce their liabilities simultaneously. Governments of different countries have broken records in their level of EFF in different years after the credit crunch: the UK in 2008/09 (a faster reaction to the financial crisis and bank bailouts), Germany in 2010, Spain and France in 2012. As a result, RD sectors, by expanding gross items of financial balance sheets, increase the proportion of transactions financed by debt and decrease the proportion financed by disposable income (Bezemer, 2010; Keen, 2015). This enhances the dependency of RD sectors on the liabilities made available by the financial sector (at both the domestic and the international levels).

The continental financial institutions collect or deliberately create financial assets in excess of real economic needs until 2008, thereby establishing a cumulative growth in the volume of financial assets and liabilities in the whole EU14 zone. FC yearly value of EFF (equivalent to $30 \%$ of EU14 GDP) is nearly double that of NFC and six times higher than $\mathrm{HH}$ in the earlier years (1999-2002), and rises progressively to a level 7 times higher than NFC and 15 times higher than $\mathrm{HH}$ in 2007 (equivalent to $70 \%$ of EU14 GDP). The EFF of the RoW sector isolates the share of financial transactions that are carried out across countries and is more than half the value of FC before 2008, less than half after 2008. This confirms the high degree of internationalisation of financial markets, but also the restraint in the balance of payments' financial account flows that occurred in the aftermath of the credit crunch across EU countries, especially in the Eurozone.

The crisis and the subsequent economic slowdown have brought about a fall in the creation of excess finance at a continental level, and a partial shift in the debt burden to governments. The extent of the EFF of the 

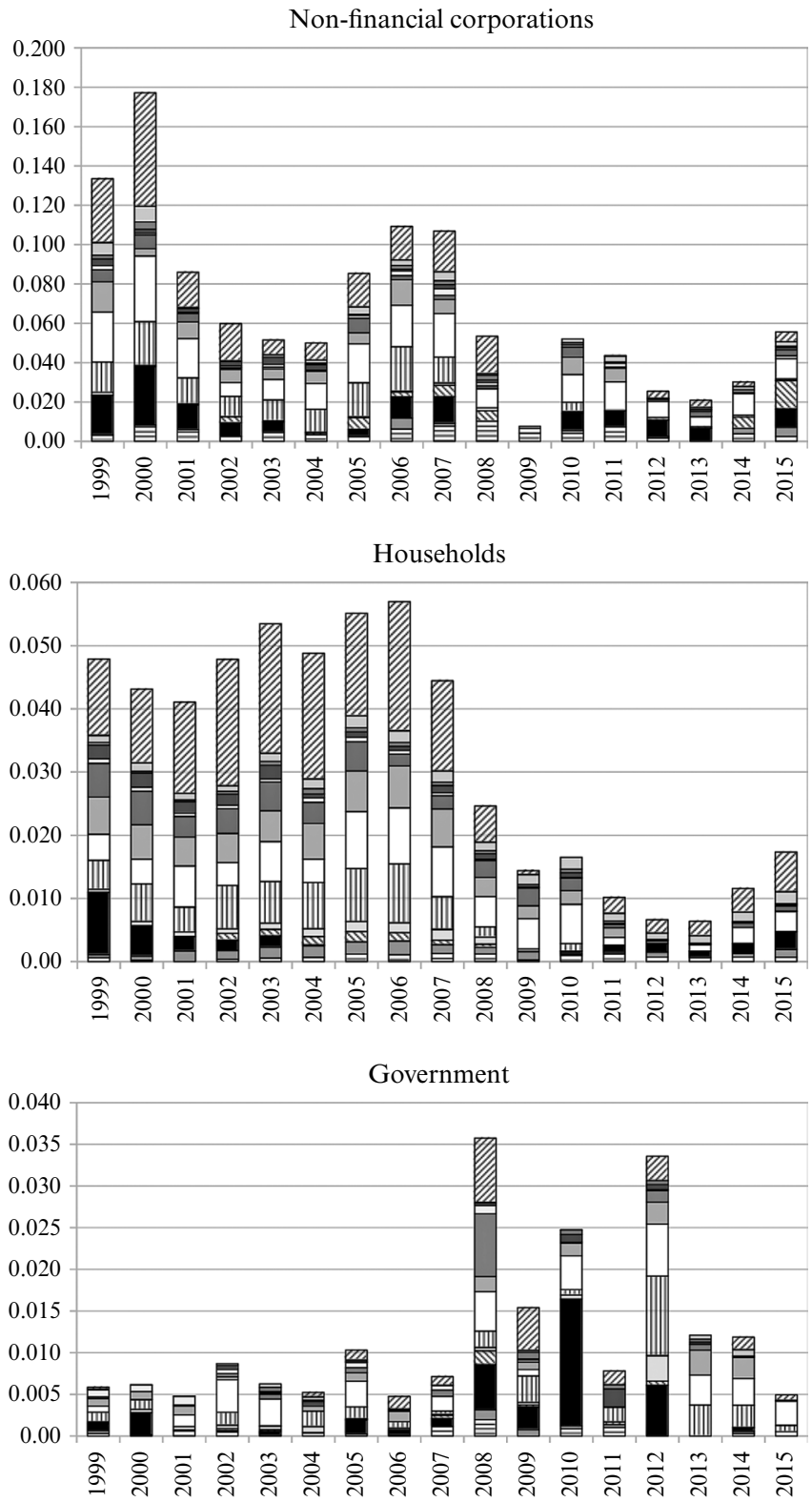

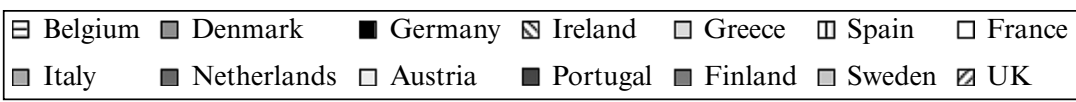

Figure 1.2 Excess financial flows by sector and country 

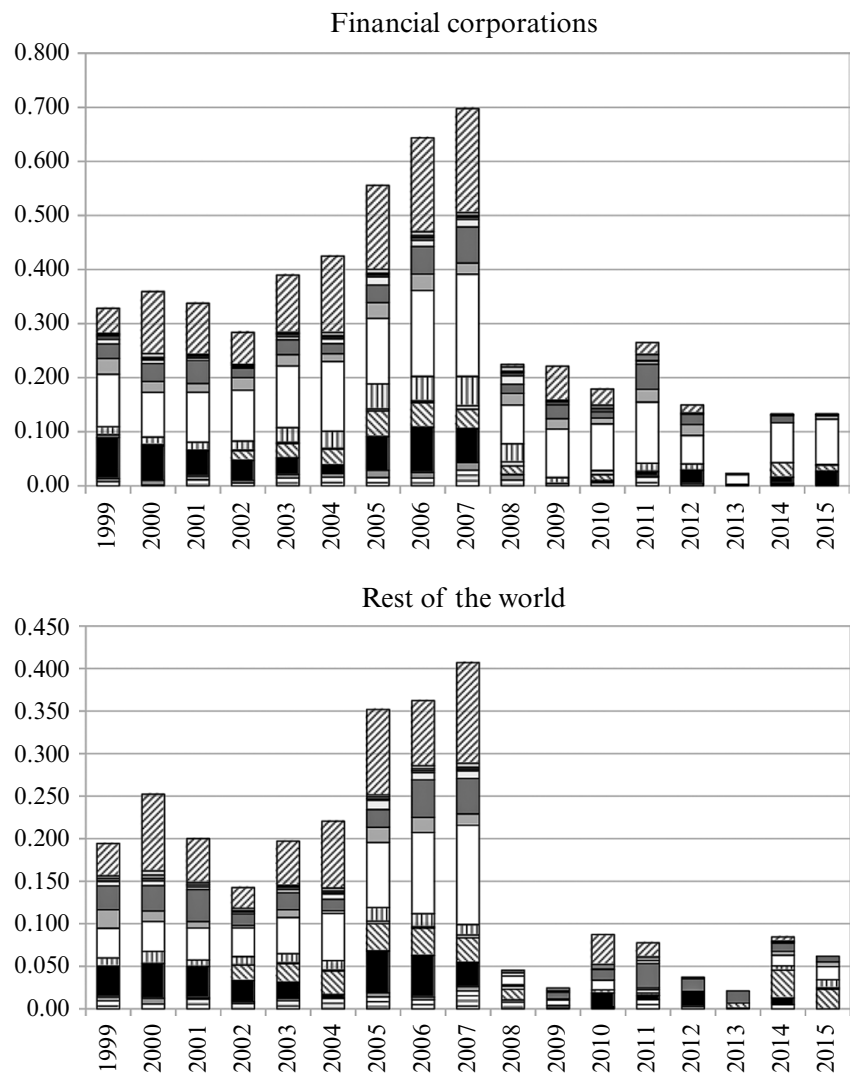

\begin{tabular}{|c|c|c|c|c|c|}
\hline \begin{tabular}{|l} 
Belgium \\
$\square$ Italy
\end{tabular} & $\begin{array}{l}\square \text { Denmark } \\
\square \text { Netherlands }\end{array}$ & 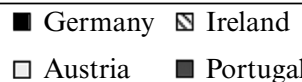 & $\begin{array}{l}\square \text { Greece } \\
\square \text { Finland }\end{array}$ & $\begin{array}{l}\square \text { Spain } \\
\square \text { Sweden }\end{array}$ & $\begin{array}{l}\square \text { France } \\
\square \text { UK }\end{array}$ \\
\hline
\end{tabular}

\section{Figure 1.2 (continued)}

financial sector has decreased sharply, even in relative terms with respect to RD sectors: in 2015, the EFF is of the order of magnitude of $10 \%$ of EU14 GDP for FC, $1 \%$ for GOV, $2 \%$ for $\mathrm{HH}$ and $5 \%$ for NFC. It should be remarked, thus, that excess finance has not disappeared. While the yearly flow is definitely lower than that of the pre-crisis period, and although it is still constant, nevertheless it is not zero. Neither in the borrowing exceeding investment proxy (Section 3), nor in the EFF proxy can a clear tendency to reduce the size of the financial stocks to levels comparable with those of the 1990s be envisaged: the proportion of financial balance sheet stocks of the FC sector is still close to the highest levels reached in 2007. This is 
not necessarily a signal of unchanged danger, as balance sheet items of the central banks rose and many toxic assets have been cleared away from non-banking financial firms. A more detailed assessment of the current stability of the financial sector requires a more thorough analysis of the composition of the financial portfolios, which is outside the scope of this study. What is worth noticing, however, as a potential warning, is the pathdependency of the size of the financial sector, whose level, eight years after the crisis, was as large as it was just before it (Spanò, 2015; Tissot, 2016).

\section{TRANSACTIONS AND VALUATION EFFECTS}

Changes in sectorial balance sheets are affected by financial transactions, resulting from deliberate decisions, and from valuation effects, resulting mainly from market price changes. In this section we compare both the sources of changes in the values of assets and liabilities and we underline their relative importance. From the analysis of the data, it is possible to establish that valuation effects are not only strongly associated with changes in the size of financial balance sheets (gross values of assets and liabilities), but they are also heavily associated with changes in the net value. We first focus on gross values and, subsequently, on the net values of financial balance sheets.

Table 1.2 reports the median values to GDP ratios of all EU14 countries resulting from transactions (Panel A) and from valuations (Panel B). Assets are divided into two typologies, labelled formal and informal, as defined in Section 2. Valuation effects due to price changes hit informal more than formal types of assets.

The HH sector increases net lending in informal assets and net borrowing in formal assets from financial transactions. This is consistent with the analysis of excess finance in the previous two sections and suggests that part of the borrowing, especially before 2008, was channelled to financial transactions in informal assets. The change in valuation of informal assets is positive for $\mathrm{HH}$ in normal years and negative in the years of financial crisis, i.e. in 2000-2002 and in 2008 (the latter fall being huge: $-18 \%$ of GDP the median, $-21 \%$ the mean). The size of the valuation effects of informal assets is of the same order of magnitude as flows from transactions, thereby leading to double the value of flows deliberately generated and boosting the asset side of $\mathrm{HH}$ financial balance sheets.

The NFC sector also increases net lending in informal assets and, before 2008 , net borrowing in formal assets. The change in valuation of informal liabilities mirrors that observed for $\mathrm{HH}$. The sign reverses in the years of 


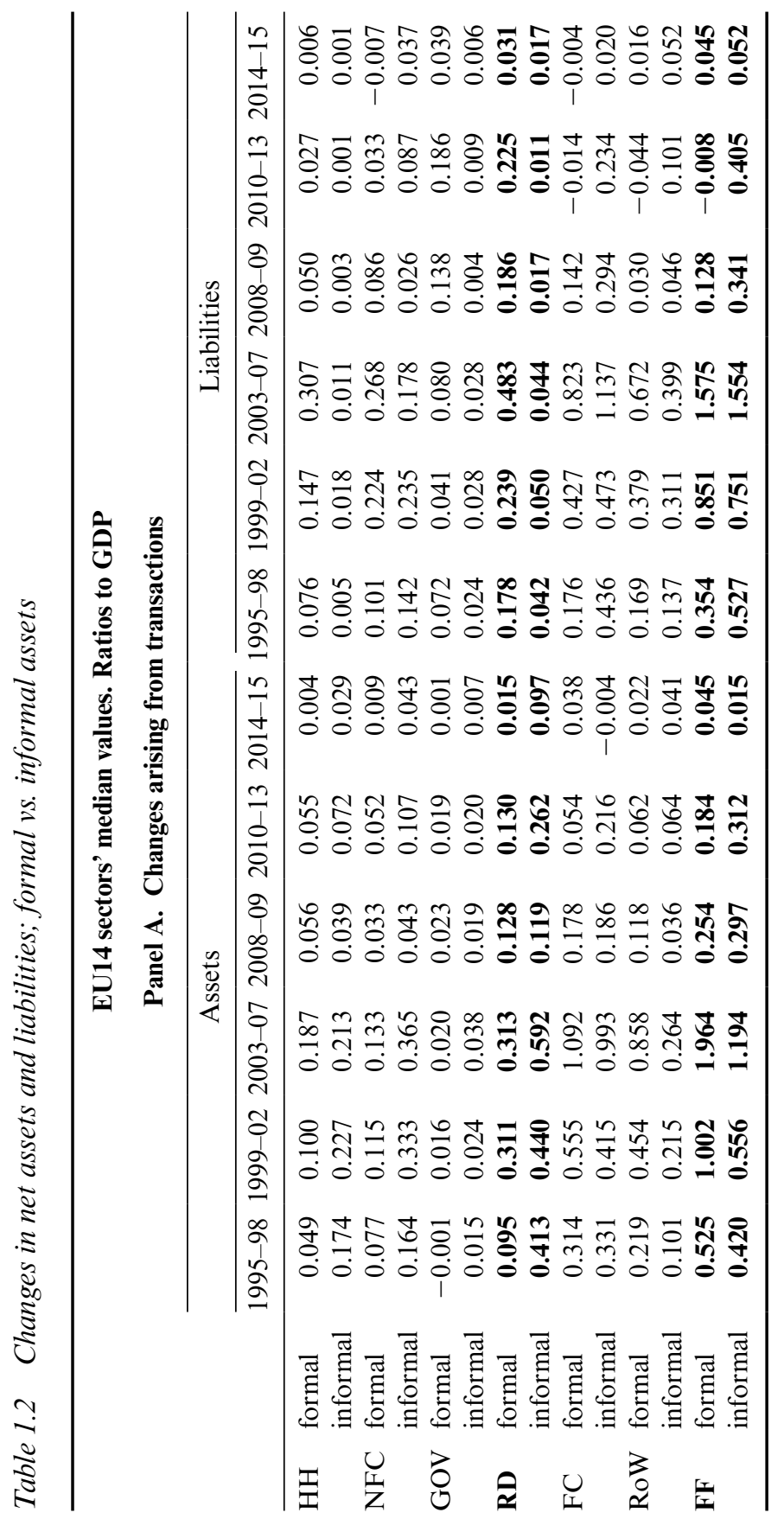




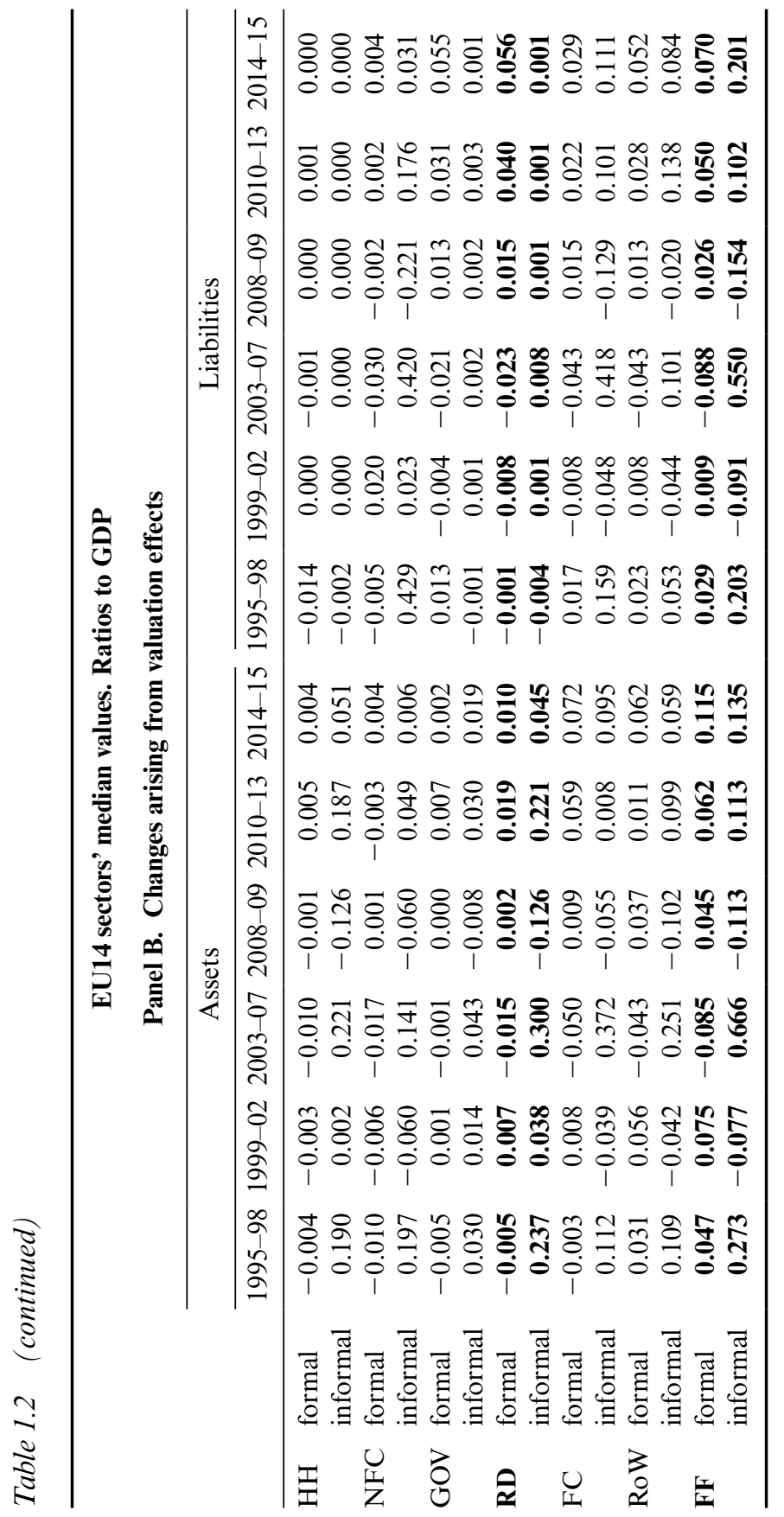


financial crisis, in 2000-2002 and in 2008 (when the median gain from the falling value of informal liabilities is around $32 \%$ of GDP). It can also be observed that the median size of valuation effects is generally higher than the median size of flows from transactions, heavily boosting both sides (the liability side slightly more) of the NFC financial balance sheets.

The GOV sector, before 2008, increases formal liabilities more than formal assets and raises net formal debt, but to a much lower extent compared to HH and NFC: GOV median value is generally not higher than $6 \%$ per year, whereas NFC and $\mathrm{HH}$ together increased formal liabilities by around $10.5 \%$ per year from 2000 to 2008 . A radically different trend can be observed after 2008, where GOV boosts the flows of formal liabilities (4.5\% on average from 2009 to 2015), whereas $\mathrm{HH}$ and NFC reduce them (to $1.4 \%$ from 2009 to 2015 ). As already noted in Section 4, this is clearly the result of the tentative policy cushioning the effects of the crisis by replacing assets. Informal transactions in assets and liabilities for GOV play only a small role. The size of valuation effects is increasing after the crisis (progressively increasing the value of GOV formal liabilities in 2011, 2012 and 2014).

The FC increases formal assets more than formal liabilities over all 20 years considered, therefore raising the net formal credit position to RD and RoW. This does not imply that the FC credit position grows in an unbalanced way, as an important part of the fixed-income assets and liabilities are domestic interbank credit and deposits, which are registered as informal asset transactions (see Section 2). What is important to notice is that the overall size of FC transaction flows rises, from above $20 \%$ of GDP per year in the second half of the 1990 s to $80 \%$ in 2007 , then falls back to $20 \%$ per year. It doubles from 1.3 times the size of all RD sector financial transactions (1995-1998) to 2.3 times (2003-2007) and then it falls after the crisis to reach 0.3 in $2014-2015$. The change in valuation of FC informal liabilities is higher than that of informal assets, both in normal years and in the years of financial crisis (2001-2002, 2008). Meanwhile, the valuations of formal assets increase after the crisis, as the mirror side of increasing the valuations of liabilities of GOV.

The RoW increases the flows of assets and liabilities (formal and informal) before 2008 and sharply falls in the following years. The size of financial flows is smaller but comparable to that of FC. Overall, the FF sector flows, summing FC and RoW, are spectacularly higher than RD flows before 2008 (from 2003 to 2007, liabilities grow six times higher, assets 3.5 times higher), and then fall after the 2008 crisis.

Overall, it is possible to establish that the yearly impact of the valuation effects on the size of both sides (assets and liabilities) of the sectorial balance sheet is all but negligible. This is already worthy of notice, as it implies 
the precarious balance sheets of institutions and individuals holding and controlling the allocation of financial assets. But valuation effect is also heavily associated to the net financial position of sectors. Table 1.3 compares the correlation of the sectorial net financial position, measured from the sectorial balance sheet, to both net saving (resulting from transactions) and the net valuation effect (resulting from market price changes). Correlations refer to single countries as well as to median and average values. The result is unambiguous: net valuation effects are positively and more highly correlated with changes in net financial positions than is net saving. This suggests that sectorial net financial positions are more affected by the decisions on the portfolio allocation of the financial instruments (especially the non-fixed income ones, which are more exposed to price volatility) than by accumulation patterns anchored to real economic activities (saving and investment).

The observed impact of the valuation effects on the sectorial balance sheets is consistent with several studies, inspired by Minsky's financial instability hypothesis, which emphasises how the validation of optimistic expectations (rising asset prices) drives rising bank lending and the deterioration of financial ratios, until the moment where debtors perceive the burden of their debt to be unsustainable and/or the creditors perceive the borrowers to be unreliable, and the crisis is triggered (Minsky, 1982; Taylor and O'Connel, 1985; Ryoo, 2013).

This study has established that the twofold boom in stock and housing markets associated to growing indebtedness, observed in the decade before the crisis (Palma, 2009; Stockhammer and Wildauer, 2016), can be empirically described as a combined effect of deliberate decisions to create new financial flows exceeding real economic transactions (analysed in the last two sections), and price effects that are not directly under the control of individuals or institutions (analysed in this section). Before 2008, excess finance had to increase every year to transact existing assets with increasing value. The fact that, in the years following the crisis, the size of the financial sector and the volume of existing financial wealth has not reversed the sign significantly should lead us to think that: on the one hand, as Seccareccia (2017) argues, monetary policy after the crisis has generally preserved the value of the existing stock of financial assets; and, on the other hand, valuation effects could still be a potential amplifier of a new wave of deliberate change in financial flow transactions.

\section{CONCLUSION}

This work has developed a methodology for analysing how superfluous financial flows grow and how they are allocated between sectors with 


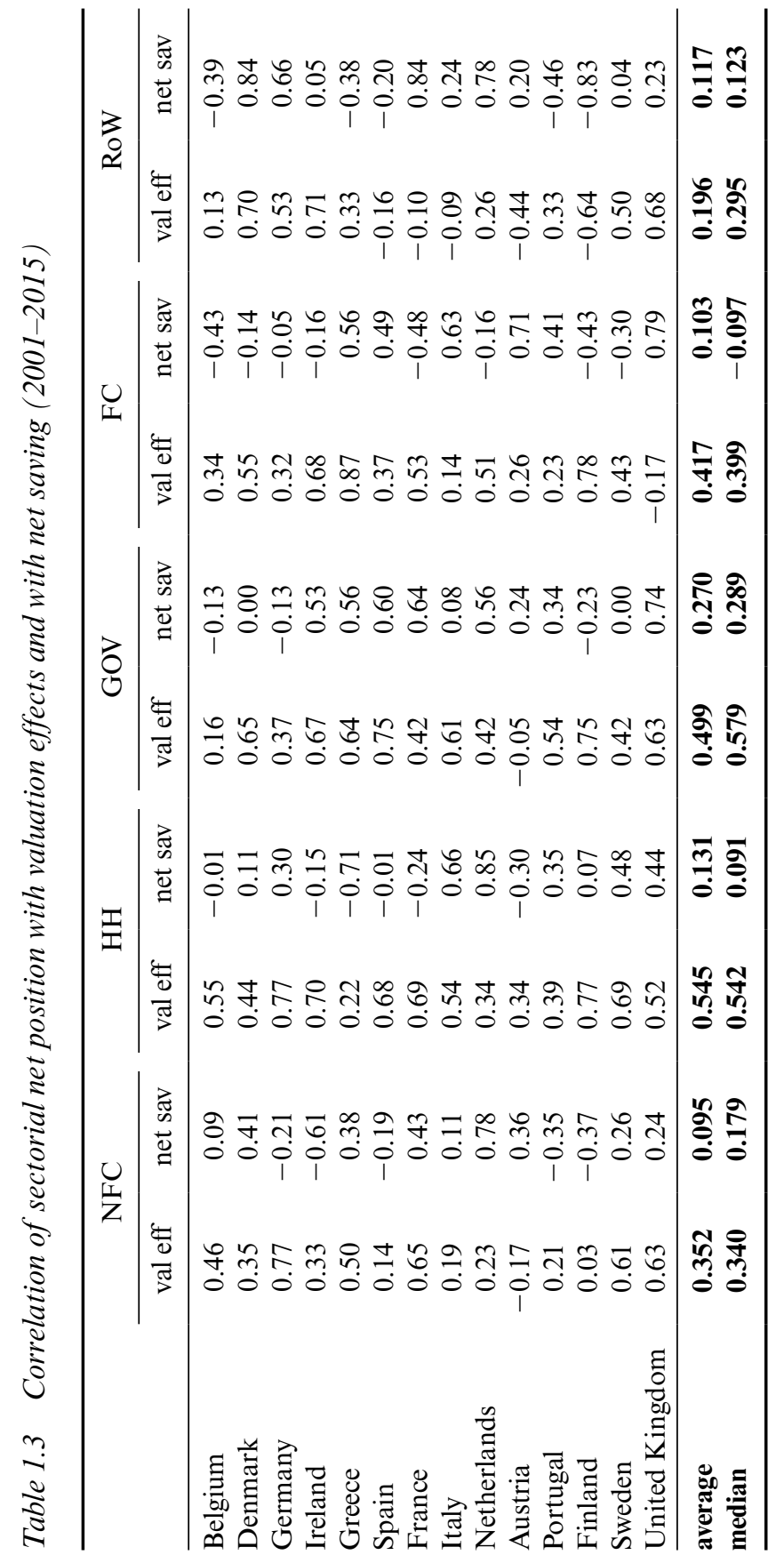


different functions (purchasing power creators vs. users) and between different economic activities (real production vs. wealth appropriation).

The methodology, based on a stock-flow consistent accounting framework, has been validated by analysing the composition of the yearly changes in financial balance sheets across the sectors of 14 founder countries of the European Union over 20 years. Two proxies have been used to separate financial transaction flows that are connected to the determination of current real income (decisions on production and spending) from transaction flows involving assets only (either pure financial or financial for real). Moreover, by grouping the institutional sectors into two macro sectors, it has been possible to separate and quantify, albeit approximately, flows that are channelled to the real domestic (RD) sector and flows that only circulate within the foreign and financial (FF) sector. Finally, changes in the market value of existing and newly created financial assets have been analysed to assess their incidence in sectorial balance sheets.

The empirical analysis has emphasised that an increasing amount of credit in the EU14 group of countries has involved transactions of assets already in place (housing, stock market) or of newly generated financial assets without contributing to the generation of real income. A prevalent and growing share of the gross excess finance has circulated within the domestic and foreign financial sector only. Investments aimed at purchasing existing wealth appear to have been perceived as a safer line of credit by banks in search of creditworthy customers, compared to investments aimed at transforming the productive structure of the economy.

The RD sector, considered as a single aggregate, increased its gross asset and liability positions in excess of its real economic activities over the entire period. Before the credit crunch crisis in 2008, this was the result of non-financial corporations (NFC) and households (HH) increasing indebtedness and simultaneously purchasing assets. After the 2008 crisis, governments increased excess liabilities to the private sectors, to cushion the effects of the financial crisis by draining the private sector's liabilities (including those of the financial system) accumulated in previous years.

Before the crisis, the Financial and foreign sector (FF) deliberately created purchasing power and increased financial transaction flows to an extent that is highly disproportionate with respect to the RD sector. The flow of finance circulating within the financial sector reached levels equivalent to $70 \%$ of all the EU14 group's GDP, 7 times higher than the excess finance of non-financial corporations and 15 times higher than that of households. During the crisis and the following years of great recession, the FF sector reduced gross financial flows more dramatically than the RD sector. While this has certainly contributed to economic recession or 
stagnation, it has not reduced the size of financial assets and the leverage of the financial sector across the continent.

Price effects are of the same order of magnitude as private sector transaction flows and they do not only affect the gross values of balance sheets, but also the sectorial net financial position. Valuation effects interacted with deliberate decisions on finance creation in a self-propelling process, where rising values of transactions required increasing amounts of borrowing, an endogenous process culminating in balance sheets deterioration being perceived as unsustainable. The subsequent great recession, overall, has preserved the value of the existing financial stock.

\section{NOTES}

1. For a review of this approach from a historical perspective, see Bezemer (2010).

2. Non-financial transactions (nasa_10_nf_tr), Financial transactions (nasa_10_f_tr), Financial balance sheets (nasa_10_f_bs).

3. In this accounting framework, real transactions in goods include durables produced in past periods, such as existing houses or second-hand cars. A purchase of a real asset is accounted twice, as an investment for the sector purchasing it and as a negative investment of the equivalent amount for the sector selling it. In national accounting, where all sectorial balances are aggregated, transactions in real assets are netted out and cannot be observed.

4. To be philologically more accurate, Schumpeter did not refer to 'new investments' in quantitative terms, but to investment in new combinations, i.e. innovations introducing new methods of production or new types of commodities.

\section{REFERENCES}

Bernanke B.S. (2000), Essays on the Great Depression, Princeton: Princeton University Press.

Bezemer, D.J. (2010), Understanding financial crisis through accounting models, Accounting, Organizations and Society, 35, 676-688.

Bezemer, D.J. (2011), Causes of financial instability: don't forget finance, Levy Economics Institute, Working Paper 665.

Crotty, J. (2008), Structural causes of the global financial crisis: a critical assessment of the 'New Financial Architecture', University of Massachusetts, Department of Economics, Working Paper 14.

De Grauwe, P. (2013), The political economy of the euro, Annual Review of Political Science, 16, 153-170.

Epstein, J. (2005) (ed.), Financialization and the World Economy, Cheltenham, UK and Northampton, MA, USA: Edward Elgar.

Erturk, I., J. Froud, J. Sukhdev, A. Leaver and K. Williams (2008), Financialization at Work, Oxford: Routledge.

Febrero, E., J. Uxò and F. Bermejo (2018), The financial crisis in the Euro Zone. A balance of payments crisis with a single currency? Review of Keynesian Economics, 6, 221-239. 
Gallino, L. (2005), L'impresa irresponsabile, Turin: Einaudi.

Godley, W. and M. Lavoie (2007), Monetary Economics: An Integrated Approach to Credit, Money, Income, Production and Wealth, London: Palgrave Macmillan.

Graziani, A. (2003), The Monetary Theory of Production, Cambridge: Cambridge University Press.

Keen, S. (2010), Solving the paradox of monetary profits, Economics. Open-Access, Open-Assessment E-Journal, 4, 1-32.

Keen, S. (2011), Debunking Economics, London: Zed Books.

Keen, S. (2015), Post-Keynesian theories of crisis, American Journal of Economics and Sociology, 74, 298-324.

Keynes, J.M. (1936), The general theory of employment, interest and money, in Collected Writings, 7, London: Macmillan.

Keynes, J.M. (1937), Alternative theories of the rate of interest, in Collected Writings, 14, London: Macmillan, 210-215.

Kindleberger, C. (1986), Manias, Panics, and Crashes: A History of Financial Crises, New York: Wiley.

Krippner, G. (2005), The financialization of the American economy, SocioEconomic Review, 3, 173-208.

Lapavistas, C. (2011), Theorizing financialization, Work, Employment and Society, $25,611-626$.

Lavoie, M. (2014), Post-Keynesian Economics: New Foundations, Cheltenham, UK and Northampton, MA, USA: Edward Elgar.

Lavoie, M. (2015), The Eurozone: similarities and differencies from Keynes's plan, International Journal of Political Economy, 44, 3-17.

Lordon, F. (2011), L'effreyante passivité de la 're-regulation financière', in Les Economistes Atterrés, eds., Changer d'économie!, 223-244. Paris: Les Liens qui Libèrent (LLL).

Martin, R. (2002), Financialization of Daily Life, Philadelphia, PA: Temple University Press.

Michell J. (2017), Do shadow banks create money? 'Financialisation' and the monetary circuit, Metroeconomica, 68, 354-377.

Minsky, H. (1982), Can 'It' Happen Again? Essays on Instability and Finance, New York: M.E. Sharpe.

Minsky, H. (1986), Stabilizing an Unstable Economy, New York: McGraw-Hill.

Mitchell, W. (2016), Eurozone Dystopia. Groupthinking and Denial on a Grand Scale, Cheltenham, UK and Northampton, MA, USA: Edward Elgar.

Nersisyan, Y., and L.R. Wray (2010), The global financial crisis and the shift to shadow banking, Levy Economics Institute, Working Paper 587.

Onaran, O., Stockhammer, E., and Graft, L. (2011), Financialization, income distribution and aggregate demand in the USA, Cambridge Journal of Economics, $35,637-61$.

Palma, J.G. (2009), The revenge of the market on the rentiers. Why neo-liberal reports of the end of history turned out to be premature, Cambridge Journal of Economics, 33, 829-869.

Pollin, R. (2007), The resurrection of the Rentier, New Left Review, 46, 140-153.

Rochon L.P. (1999), Credit, Money and Production. An Alternative Post-Keynesian Approach, Cheltenham, UK and Northampton, MA, USA: Edward Elgar.

Ryoo. S. (2013), Minsky cycles in Keynesian models of growth and distribution, Review of Keynesian Economics, 1(1), 37-60.

Schumpeter, J.A. (1912), The Theory of Economic Development: An Inquiry into 
Profits, Capital, Credit, Interest, and the Business Cycle, Cambridge, MA: Harvard University Press, 1949.

Seccareccia M. (2017), Which vested interests do central banks really serve? Understanding central bank policy since the global financial crisis, Journal of Economic Issues, 51(2), 341-50.

Spanò, M. (2015), Financial assets overhang in Europe, Journal of Post Keynesian Economics, 37, 303-527.

Stockhammer, E. (2015), Rising inequality as a cause of the present crisis, Cambridge Journal of Economics, 39, 935-958.

Stockhammer E. and R. Wildauer (2016), Debt-driven growth? Wealth, distribution and demand in OECD countries, Cambridge Journal of Economics, 40, $1609-1634$.

Storm, S. (2016), Rejoinder to Flassbeck and Lapavitsas, Institute for New Economic Thinking blog, 28 January, http://ineteconomics.org/ideas-papers/blog/ rejoinder-to-flassbeck-and-lapavitsas.

Taylor, L. and S.A. O'Connel (1985), A Minsky's crisis, The Quarterly Journal of Economics, 100, 871-885.

Tissot, B. (2016), Development of financial sectoral accounts: new opportunities and challenges for supporting financial stability analysis. Bank for International Settlements, IFC Working Papers 15.

Van Treeck, T. (2009), The political economy debate on 'financialization' - a macroeconomic perspective, Review of International Political Economy, 16, 907-944.

Wray L.R. (2012), Modern Money Theory, London: Palgrave Macmillan. 